\title{
Perbandingan Persentase Eliminasi Bakteri pada Cuci Tangan Enam Langkah dan Empat Langkah
}

\author{
Annisa Widi Rizkia ${ }^{1}$, Andani Eka Putra ${ }^{2}$, Nurhayati $^{3}$ \\ ${ }^{1}$ Fakultas Kedokteran Universitas Andalas, Padang \\ ${ }^{2}$ Bagian Mikrobiologi Fakultas Kedokteran Universitas Andalas, Padang \\ ${ }^{3}$ Bagian Parasitologi Fakultas Kedokteran Universitas Andalas, Padang
}

\begin{abstract}
A B S T R A C T
Latar Belakang. Salah satu tahap kewaspadaan standar yang efektif dalam pencegahan dan pengendalian infeksi terkait pelayanan kesehatan yang tercantum dalam PERMENKES RI no. 27 tahun 2017 ialah mencuci tangan. Mencuci tangan dapat mengurangi bakteri sampai 90\%. Sampai saat ini, cuci tangan 6 langkah sesuai standar WHO merupakan metode yang paling efektif dalam mengeliminasi mikroorganisme pada tangan.

Objektif. Untuk membandingkan keefektifan dari metode 6 langkah yang merupakan metode mencuci tangan sesuai standar WHO dibandingkan dengan metode 4 langkah yang merupakan modifikasi peneliti terhadap standar WHO.

Metode. Penelitian ini merupakan penelitian eksperimental dengan posttest and pretest control group design terhadap 12 orang subjek penelitian yang merupakan mahasiswa/i FK UNAND angkatan 2015. Subjek penelitian dibagi menjadi 2 kelompok yaitu pertama yang mencuci tangan menggunakan 6 langkah dan 4 langkah. Sampel yang diambil pada 3 area di tangan setiap subjek tersebut.

Hasil. Diperoleh rata-rata persentase eliminasi bakteri Bacillus $s p$. adalah lebih dari $80 \%$ pada kedua kelompok. Tidak terdapat

and pretest control group design on twelve subjects who are medical students of Andalas University batch 2015. Subjects were divided into two groups: the first group would wash their hands using six steps and another group using four steps. Samples were taken with a swab in three areas in the hands of each subject.

Result. Obtained the average percentage reduction of Bacillus $s p$. is more than $80 \%$ in both groups. There were no significant differences ( $p>0.05)$ in the two treatment groups. The results of the average percentage reduction of all bacteria on the hands showed significant differences $(p<0.05)$ between the groups which is the handwashing group used a six-step method (> 75\%) show a higher percentage of bacterial elimination compared to a group used four steps (<45\%).

Conclusion. There was no difference in the percentage of Bacillus sp. elimination using hand washing 6 steps and 4 steps. There is a difference in the percentage of overall bacterial elimination using 6 steps and 4 step hand washing.

Keyword: bacteria reduction, four steps hand washing, six steps hand washing
\end{abstract} perbedaan yang signifikan $(p>0,05)$ pada kedua kelompok perlakuan. Hasil rata-rata persentase eliminasi keseluruhan bakteri pada tangan menunjukkan perbedaan yang signifikan $(p<0,05)$ antar kelompok, dimana kelompok yang mencuci tangan menggunakan metode 6 langkah (>75\%) lebih tinggi persentase eliminasi bakteri dibandingkan 4 langkah (<45\%).

Kesimpulan. Tidak terdapat perbedaan persentase eliminasi bakteri Bacillus sp. mencuci tangan 6 langkah dan 4 langkah. Terdapat perbedaan persentase eliminasi bakteri secara keseluruhan pada mencuci tangan 6 langkah dan 4 langkah.

Kata kunci: 4 langkah cuci tangan, 6 langkah cuci tangan, eliminasi bakteri

Background. One of the standard precautions that are effective in preventing and controlling healthcare-associated infections (HAls) listed in a regulation made by the Ministry of Healthcare of Republic Indonesia no. 27 of 2017 is hand washing. Handwashing can reduce bacteria by up to 90\%. Nowadays, six-step handwashing according to WHO standards is the most effective method of eliminating microorganisms in the hands.

Objective. To compare the effectiveness of handwashing with six steps that comply with WHO standards and four steps which is a modification of WHO standards.

Method. This study was an experimental study with posttest

\section{Apa yang sudah diketahui tentang topik ini?}

Cuci tangan 6 langkah sesuai standar WHO merupakan metode yang paling efektif dalam mengeliminasi mikroorganisme pada tangan dengan persentase eliminasi bakteri yang bervariasi.

\section{Apa yang ditambahkan pada studi ini?}

Tidak terdapatnya perbedaan persentase eliminasi bakteri Bacillus sp. pada mencuci tangan 6 langkah dan 4 langkah. Namun, terdapat perbedaan persentase eliminasi bakteri secara keseluruhan pada mencuci tangan 6 langkah dan 4 langkah.

\section{CORRESPONDING AUTHOR}

Name: Annisa Widi Rizkia

Phone: +6282387657519

E-mail: Annisa.wrkia@gmail.com

\section{ARTICLE INFORMATION}

Received: September $23^{\text {rd }}$, 2020

Revised: October $15^{\text {th }}, 2020$

Available online: October $31^{s t}, 2020$ 


\section{Pendahuluan}

Infeksi termasuk kedalam penyebab utama tingginya morbiditas dan mortalitas di rumah sakit dan fasilitas pelayanan kesehatan lainnya hingga saat ini. ${ }^{1}$ Resiko infeksi terkait pelayanan kesehatan merupakan masalah yang menjadi perhatian di seluruh dunia. ${ }^{2}$ Menurut World Health Organization(WHO), sekitar 15\% dari semua pasien yang dirawat di rumah sakit menderita infeksi terkait pelayanan kesehatan atau yang dikenal juga sebagai infeksi nosokomial. Insiden dari infeksi ini sekitar 3,5\% - 12\% pada negara maju dan 5,7\% - 19,1\% pada negara berkembang. Frekuensi infeksi ini secara keseluruhan pada negara berkembang tiga kali lebih tinggi daripada negara maju dan angka kejadiannya tiga sampai dua puluh kali lebih tinggi pada neonatus. Infeksi terkait pelayanan kesehatan ini menyumbang $4 \%$ - 56\% dari semua penyebab kematian pada neonatus, dengan tingkat kejadian $75 \%$ di Asia Tenggara dan SubSahara Afrika.

Infeksi terkait pelayanan kesehatan biasanya disebabkan oleh mikroorganisme yang sudah resisten dengan berbagai antibiotik sehingga sulit dalam menemukan terapi yang tepat. ${ }^{4} \mathrm{Hal}$ ini lah yang menyebabkan angka morbiditas dan mortalitas dari infeksi ini sangat tinggi. Permasalahan yang timbul akibat infeksi terkait pelayanan kesehatan tidak hanya meningkatkan angka morbiditas dan mortalitas tetapi juga meningkatkan kerugian finansial secara signifikan. ${ }^{5}$ Hal ini disebabkan oleh meningkatnya lama perawatan pasien, bertambanya pemeriksaan penunjang, penggunaan obat, dan penatalaksaan lainnya sehingga meningkatkan biaya perawatan. ${ }^{6}$ Oleh sebab itu, tidak hanya tenaga medis, pemerintah pun turut serta mengambil andil dalam upaya pemberantasan hal ini dengan mengeluarkan Peraturan Menteri Kesehatan Republik Indonesia (PERMENKES RI) no. 27 tahun 2017 tentang pedoman pencegahan dan pengendalian infeksi di fasilitas pelayanan kesehatan. ${ }^{7}$

Salah satu tahap kewaspadaan standar yang efektif dalam pencegahan dan pengendalian infeksi yang tercantum dalam PERMENKES RI no. 27 tahun 2017 ialah hand hygiene (kebersihan tangan). ${ }^{7}$ Hand hygiene atau cuci tangan merupakan salah satu komponen utama yang harus dilaksanakan dan dipatuhi dalam kewaspadaan standar yang direkomendasikan oleh Center of Disease Control and Prevention (CDC) dan Helathcare Infection Control Practices Advisory Commite (HICPAC) pada tahun 2002.8 Menjaga kebersihan tangan dengan cara mencuci tangan adalah metode paling praktis dan efektif dalam pencegahan infeksi terkait pelayanan kesehatan. ${ }^{9}$ Mencuci tangan dapat mengurangi bakteri sampai 90\%.10 Penelitian menunjukkan bahwa jumlah angka kuman mencuci tangan menggunakan air mengalir adalah 18,33 $\mathrm{CFU} / \mathrm{cm} 2$, sabun $3,5 \mathrm{CFU} / \mathrm{cm} 2$, dan kelompok kontrol (tanpa cuci tangan) 32,5 CFU/cm2.11 Berdasarkan penelitian yang dilakukan oleh Burton terhadap bakteri gram negatif yang terdapat pada tangan, mencuci tangan dengan air saja dapat mengurangi keberadaan bakteri sampai tersisa $23 \%$ bakteri pada tangan sedangkan dengan sabun dan air dapat mengurangi keberadaan bakteri sampai tersisa hanya $8 \%$ bakteri. ${ }^{12}$ Penggunaan handrub saat mencuci tangan dapat mengurangi mikroba mencapai $85 \%$ tergantung zat yang terkandung di dalamnya seperti etanol (60\%-85\%), isopropanol $\left(60 \%\right.$ - 80\%), dan n-propanol (60\%-80\%). ${ }^{13}$ Penelitian yang dilakukan oleh Rachmawati dkk juga membuktikan bahwa mencuci tangan dengan handrub bisa menurunkan angka kuman mencapai $90 \% .^{14}$

Cara mencuci tangan menurut buku pedoman kebersihan tangan yang dibuat oleh Pedoman Pencegahan Infeksi Rumah Sakit (PPIRS) RSUP DR. M. Djamil Padang terdiri dari 6 (enam) langkah. ${ }^{15}$ Cuci tangan 6 langkah sesuai standar WHO merupakan metode yang paling efektif dalam mengeliminasi mikroorganisme pada tangan. Hal ini dibuktikan dengan suatu penelitian telah membandingkan keefektifan antara metode cuci tangan 6 langkah dari WHO dengan metode cuci tangan 3 langkah dari CDC dengan handrub. ${ }^{16}$

Pentingnya cuci tangan pada tenaga kesehatan termasuk mahasiswa kedokteran menyebabkan peneliti tertarik untuk melakukan penelitian menegnai cuci tangan. Peneliti ingin mengetahui keefektifan dari metode 6 langkah yang merupakan metode mencuci tangan sesuai standar WHO dibandingkan dengan metode 4 langkah yang merupakan modifikasi peneliti terhadap standar WHO dengan membandingkan persentase eliminasi bakteri pada tangan sebelum 
dan sesudah dicuci dengan kedua metode tersebut.

\section{Metode}

Jenis penelitian ini adalah eksperimental dengan rancangan pretest and posttest control group yaitu dengan memberikan uji awal (pretest) sebelum diberikan perlakuan dan uji akhir (posttest) setelah diberikan perlakuan yang dilakukan kepada semua kelompok. Variabel independennya adalah mencuci tangan dengan metode enam langkah dan empat langkah dan variabel dependennya adalah presentase eliminasi bakteri. Penelitian dilakukan dari bulan Desembaer 2018 - Januari 2019 di Lab Mikrobiologi FK UNAND.

Populasi pada penelitian ini adalah mahasiswa profesi dokter FK Unand angkatan 2015. Sampel penelitian ini merupakan 12 mahasiswa profesi dokter angkatan 2015 yang memenuhi kriteria inklusi dan ekslusi. Kriteria inklusi: memiliki pengetahuan mengenai mencuci tangan enam langkah sesuai standar WHO dan mampu mempraktikannya, memiliki waktu dan kemauan bekerjasama dalam melakukan penelitian ini. Kriteria eksklusi: memiliki lesi pada tangan, sedang sakit, sedang mendapat terapi kortikosteroid, sedang mendapat terapi antibiotik topikal pada tangan, dalam siklus kemoterapi.

Mahasiswa tersebut dibagi menjadi 2 kelompok: kelompok pertama merupakan kelompok yang mencuci tangan menggunakan metode 6 langkah sesuai standar WHO dan kelompok kedua merupakan kelompok yang mencuci tangan menggunakan metode 4 langkah.

Pertama, dilakukan pembuatan suspensi bakteri. Suspensi bakteri dibuat dari pengenceran $10^{-4}$ bakteri Bacillus sp. dalam $100 \mathrm{ml}^{17}$ Pembuatan suspensi bakteri ini diawali dengan melakukan swab debu - debu yang terdapat pada jendela kemudian ditanam di media agar darah dan nutrien agar. Koloni yang tumbuh pada media tanam ini dipastikan bahwa merupakan koloni Bacillus sp. dengan melihat fenotip maupun pewarnaan gram. Koloni Bacillus $s p$ yang tumbuh diambil dengan ose dan dimasukkan kedalam larutan $\mathrm{PbS}$ lalu di homogenkan. Larutan tersebut selanjutnya disamakan kekeruhannya dengan standar McFarland 0,5. Untuk memperoleh suspensi bakteri dengan konsentrasi $10^{-4}$ dalam $100 \mathrm{ml}$ aquades/ air, digunakan rumus pengenceran sehingga diperoleh 6,6 ul larutan $\mathrm{PbS}$ tersebut dimasukkan kedalam $100 \mathrm{ml}$ aquades.

Selanjutnya, dilakukan pesiapan sampel. Peneliti melakukan inform concent kepada relawan. Setelah itu, peneliti meminta relawan mencuci tangan menggunakan alkohol dan mencelupkan tangan pada suspensi kuman yang terbuat dari pengenceran $10^{-4}$ bakteri Bacillus $s p$. dalam $100 \mathrm{ml}^{17}$ aquades dilanjutkan dengan relawan mencuci tangan menggunakan metode 4 langkah maupun 6 langkah.

Metode 4 langkah merupakan modifikasi cuci tangan 6 langkah sesuai standar WHO dengan mereduksi 2 langkah. Pereduksian dilakukan pada langkah pada saat kedua telapak tangan saling berhadapan dan jari-jari saling menyilang, gosok kedua telapak tangan, dan sela-sela jari dari bagian pangkal jari ke arah luar (ujung) serta pada langkah dimana kedua tangan saling menggenggam, jari-jari saling mengunci, punggung jari tangan satu pada telapak tangan lainnya saling menggosok.

Swab tangan dilakukan sebelum dan setelah relawan mencuci tangan. Kapas lidi yang steril diswabkan pada 3 area permukaan tangan yaitu, 1. metakarpal 2,3,4 depan tangan, 2. metakarpal 2,3,4, punggung tangan, 3 . sela jari 3 dan 4 (Gambar 1). Pemilihan tiga area swab ini merupakan area yang mewakilkan langkah yang direduksi. Kapas lidi kemudian dimasukkan kedalam media transpor yaitu larutan tioglikolat.
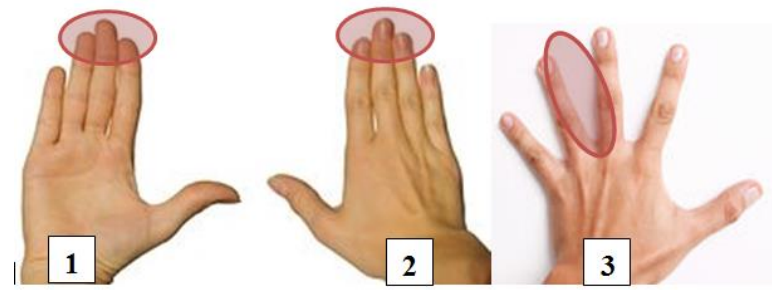

Gambar 1. Area Swab

Selanjutnya dilakukan penanaman dengan metode sebar pada medium Nutrient Agar (NA) dan diinkubasi pada suhu $37 \mathrm{C}^{\circ}$ selama sehari. Selanjutnya dilakukan penghitungan jumlah koloni mikroba. ${ }^{18,19}$

Teknik pengolahan data dilakukan dengan menyusun dan mentabulasi data hasil penelitian menurut kelompoknya, lalu disajikan dalam bentuk tabel. Analisis data menggunakan software komputer. Data dianalisis univariat dan bivariat. 


\section{Hasil}

Subjek penelitian ini merupakan 12 mahasiswa profesi dokter angkatan 2015 yang memenuhi kriteria inklusi dan ekslusi. Mahasiswa tersebut dibagi menjadi 2 kelompok: kelompok pertama merupakan kelompok yang mencuci tangan menggunakan metode 6 langkah sesuai standar WHO dan kelompok kedua merupakan kelompok yang mencuci tangan menggunakan metode 4 langkah. Selanjutnya akan di ambil sampel yang berupa swab tangan subjek penelitian pada 3 area di tangan.

\section{Jumlah Koloni Bacillus sp. Sebelum dan Sesudah Mencuci Tangan}

Tabel 1. Jumlah Koloni Bacillus sp. pada Cuci Tangan Enam Langkah

\begin{tabular}{|c|c|c|c|c|}
\hline Variabel & $\begin{array}{c}\text { Mean } \pm \text { SD } \\
\left(10^{5} \mathrm{cfu} / \mathrm{ml}\right)\end{array}$ & $\begin{array}{c}\text { Min } \\
\left(10^{5}\right. \\
\text { cfu } / \mathbf{m l})\end{array}$ & $\begin{array}{c}\text { Max } \\
\left(10^{5}\right. \\
\text { cfu/ml })\end{array}$ & $\mathbf{p}^{*}$ \\
\hline$\overline{\text { Area } 1 \text { Seb } €}$ & $9,67 \pm 11,039$ & 0 & 28 & 0,109 \\
\hline Sesudah & $0,20 \pm 0,447$ & 0 & 1 & \\
\hline Area 2 Sebelum & $1,00 \pm 1,265$ & 0 & 3 & 0,180 \\
\hline Sesudah & $0,17 \pm 0,408$ & 0 & 1 & \\
\hline Area 3 Sebelum & $45,00 \pm 98,955$ & 0 & 222 & 0,180 \\
\hline Sesudah & $1,33 \pm 1,751$ & 0 & 4 & \\
\hline
\end{tabular}

Berdasarkan tabel 1 dapat dilihat bahwa penyebaran kolonii Bacillus sp. tidak merata pada 3 area pengambilan swab. Pada kelompok subjek dengan perlakuan mencuci tangan 6 langkah, area 3 (sela jari 3 dan 4) merupakan area dengan ratarata jumlah koloni Bacillus sp. terbanyak yang ditemukan pada tangan subjek sebelum mencuci tangan yaitu $45 \times 10^{5} \mathrm{cfu} / \mathrm{ml}$. Hal ini sebanding dengan nilai maksimal jumlah koloni bakteri Bacillus sp. yang ditemukan pada area tersebut mencapai 222 koloni. Area dengan jumlah Bacillus $s p$. terendah pada kelompok pertama ini adalah area 2 (metakarpal 2,3,4 punggung tangan) dengan rata-rata koloni bakteri Bacillus sp $1 \times 10^{5}$ $\mathrm{cfu} / \mathrm{ml}$. Setelah mencuci tangan dengan menggunakan metode 6 langkah didapatkan ratarata jumlah koloni Bacillus sp tertinggi terdapat pada area 3 yaitu $1,33 \times 10^{5} \mathrm{cfu} / \mathrm{ml}$ dan terendah pada area 2 yaitu $0,17 \times 10^{5} \mathrm{cfu} / \mathrm{ml}$.
Tabel 2. Jumlah Koloni Bacillus sp. pada Cuci Tangan Empat Langkah

\begin{tabular}{cccccc}
\hline Variabel & $\begin{array}{c}\text { Mean } \mathbf{+} \text { SD } \\
\left(\mathbf{1 0}^{\mathbf{5}} \mathbf{c f u} / \mathbf{m l}\right)\end{array}$ & $\begin{array}{c}\text { Min } \\
\mathbf{( 1 0 ^ { 5 }} \\
\mathbf{c f u} / \mathbf{m l})\end{array}$ & $\begin{array}{c}\text { Max } \\
\mathbf{( 1 0 ^ { 5 }}\end{array}$ & $\mathbf{p}^{*}$ \\
$\mathbf{c f u} / \mathbf{m l})$ & \\
\hline Area 1 & Sebelum & $5,00 \pm 7,694$ & 0 & 20 & 0,068 \\
Area 2 & Sesudah & $0,67 \pm 1,633$ & 0 & 4 & \\
& Sebelum & $13,00 \pm 18,155$ & 0 & 44 & 0,068 \\
Area 3 & Sebudah & $0,17 \pm 0,408$ & 0 & 1 & \\
& Sesudah & $0,67 \pm 1,211$ & 0 & 3 & 0,180 \\
*Wilxocon Test & $0,17 \pm 0,408$ & 0 & 1 & \\
\hline
\end{tabular}

Berdasarkan tabel 2 dapat dilihat bahwa pada kelompok subjek dengan perlakuan mencuci tangan 4 langkah, area 2 merupakan area dengan rata-rata jumlah koloni Bacillus sp. terbanyak yang ditemukan pada tangan subjek sebelum mencuci tangan yaitu $13 \times 10^{5} \mathrm{cfu} / \mathrm{ml}$. Area dengan jumlah koloni Bacillus sp. terendah pada kelompok kedua ini adalah area 3 dengan ratarata koloni bakteri Bacillus sp. 0,67 x $10^{5} \mathrm{cfu} / \mathrm{ml}$. Setelah mencuci tangan dengan menggunakan metode 4 langkah didapatkan rata-rata jumlah koloni bakteri Bacillus sp. tertinggi terdapat pada area 1 (metakarpal 2, 3, 4 depan tangan) yaitu $0,67 \times 10^{5} \mathrm{cfu} / \mathrm{ml}$ dan terendah pada area 2 dan 3 yaitu $0,17 \times 10^{5} \mathrm{cfu} / \mathrm{ml}$.

Tabel 1 dan 2 menunjukkan tidak tampak perubahan yang signifikan $(\mathrm{p}>0,05)$ antara jumlah koloni Bacillus sp. sebelum mencuci tangan dan sesudah mencuci tangan pada kedua kelompok.

\section{Jumlah Total Koloni Bakteri Sebelum dan Sesudah Mencuci Tangan}

Tabel 3. Jumlah Total Koloni Bakteri Sebelum dan Sesudah Mencuci Tangan Enam Langkah

\begin{tabular}{cccccc}
\hline Variabel & $\begin{array}{c}\text { Mean } \pm \text { SD } \\
(\mathbf{1 0 5} \mathbf{c f u} / \mathbf{m l})\end{array}$ & $\begin{array}{c}\text { Min } \\
\mathbf{( 1 0 5} \\
\mathbf{c f u} / \mathbf{m l})\end{array}$ & $\begin{array}{c}\text { Max } \\
\mathbf{( 1 0 5} \\
\mathbf{c f u} / \mathbf{m l})\end{array}$ & $\mathbf{p}^{*}$ \\
\hline Area 1 Sebelum & $39,50 \pm 55,338$ & 0 & 147 & 0,043 \\
Area 2 & Sebudah & $5,60 \pm 11,415$ & 0 & 26 & \\
& Sebudah & $28,50 \pm 25,587$ & 0 & 64 & 0,027 \\
Area 3 & Sebelum & $9,00 \pm 2,944$ & 0 & 12 & \\
& Sesudah & $7,01,40 \pm 192,832$ & 0 & 446 & 0,043 \\
\hline
\end{tabular}

*Wilxocon Test

Berdasarkan tabel 3 dapat dilihat bahwa pada kelompok subjek dengan perlakuan mencuci tangan 6 langkah, area 3 (sela jari 3 dan 4) merupakan area dengan rata-rata total koloni bakteri terbanyak yang ditemukan pada tangan subjek sebelum mencuci tangan yaitu $101,40 \mathrm{x}$ $10^{5} \mathrm{cfu} / \mathrm{ml}$. Area dengan total koloni bakteri 
terendah pada kelompok pertama ini adalah area 2 (metakarpal 2,3,4 punggung tangan) dengan rata-rata total koloni bakteri $28,5 \times 10^{5} \mathrm{cfu} / \mathrm{ml}$. Setelah mencuci tangan dengan menggunakan metode 6 langkah didapatkan rata-rata jumlah total koloni bakteri tertinggi terdapat pada area 2 yaitu $9 \times 10^{5} \mathrm{cfu} / \mathrm{ml}$ dan terendah pada area 1 yaitu $5,6 \times 10^{5} \mathrm{cfu} / \mathrm{ml}$. Tampak perubahan yang signifikan $(\mathrm{p}<0,05)$ antara jumlah bakteri sebelum mencuci tangan dan sesudah mencuci tangan pada kelompok yang mencuci tangan menggunakan metode 6 langkah pada semua area swab.

Tabel 4. Jumlah Total Koloni Bakteri Sebelum dan Sesudah Mencuci Tangan Empat Langkah

\begin{tabular}{|c|c|c|c|c|}
\hline Variabel & $\begin{array}{c}\text { Mean } \pm \text { SD } \\
\left(10^{5} \mathrm{cfu} / \mathrm{ml}\right)\end{array}$ & $\begin{array}{c}\text { Min } \\
\left(10^{5}\right. \\
\text { cfu/ml })\end{array}$ & $\begin{array}{c}\text { Max } \\
\left(10^{5}\right. \\
\text { cfu/ml) }\end{array}$ & $\mathbf{p}^{*}$ \\
\hline Area 1 Sebelum & $47,67 \pm 72,869$ & 0 & 191 & 0,225 \\
\hline Sesudah & $20,67 \pm 24,492$ & 0 & 62 & \\
\hline Area 2 Sebelum & $92,83 \pm 101,559$ & 0 & 240 & 0,043 \\
\hline Sesudah & $58,67 \pm 77,389$ & 0 & 163 & \\
\hline Area 3 Sebelum & $44,50 \pm 56,596$ & 0 & 142 & 0,068 \\
\hline Sesudah & $30,00 \pm 36,677$ & 0 & 80 & \\
\hline
\end{tabular}

Berdasarkan tabel 4 dapat dilihat bahwa pada kelompok subjek dengan perlakuan mencuci tangan 4 langkah, area 2 (metakarpal 2,3,4 punggung tangan) merupakan area dengan ratarata total koloni bakteri terbanyak yang ditemukan pada tangan subjek sebelum mencuci tangan yaitu $92,83 \times 10^{5} \mathrm{cfu} / \mathrm{ml}$. Area dengan total koloni bakteri terendah pada kelompok pertama ini adalah dengan rata-rata total bakteri $44,5 \times 10^{5} \mathrm{cfu} / \mathrm{ml}$. Setelah mencuci tangan dengan menggunakan metode 4 langkah didapatkan ratarata jumlah total koloni bakteri tertinggi terdapat pada area 2 yaitu $58,67 \times 10^{5} \mathrm{cfu} / \mathrm{ml}$ dan terendah pada area 1 yaitu 20,67 x $10^{5} \mathrm{cfu} / \mathrm{ml}$. Tidak tampak perubahan yang signifikan $(p>0,05)$ antara jumlah bakteri sebelum mencuci tangan dan sesudah mencuci tangan pada kelompok yang mencuci tangan menggunakan metode 4 langkah di area 1 dan 3.

\section{Persentase Eliminasi dan Eliminasi Total Bakteri pada Mencuci Tangan Menggunakan Metode 6 Langkah dan 4 Langkah}

Tabel 5. Persentase Eliminasi dan Eliminasi Total Bakteri Bacillus sp. pada Mencuci Tangan Enam Langkah dan Empat Langkah

\begin{tabular}{cccc}
\hline Variabel & 6 Langkah & 4 Langkah & \multirow{2}{*}{$\mathbf{p}^{*}$} \\
\cline { 2 - 3 } & Mean \pm SD (\%) & Mean \pm SD (\%) & \\
\hline Eliminasi & & & \\
Area 1 & $98,00 \pm 3,464$ & $83,25 \pm 33,500$ & 0,919 \\
Area 2 & $100,00 \pm 0,00$ & $96,50 \pm 7,000$ & 0,646 \\
Area 3 & $82,50 \pm 21,920$ & $83,50 \pm 23,335$ & 0,400 \\
*Mann-whitney Test & & \\
Eliminasi Total & & & \\
Area 1 & $86,00 \pm 25,990$ & $37,40 \pm 51,656$ & 0,030 \\
Area 2 & $75,00 \pm 34,940$ & $44,83 \pm 31,429$ & 0,093 \\
Area 3 & $80,20 \pm 21,487$ & $31,80 \pm 31,436$ & 0,017 \\
*Independent T Test & & \\
\hline
\end{tabular}

Berdasarkan tabel 5 pada eliminasi bakteri menunjukkan tidak terdapatnya perbedaan signifikan $(\mathrm{p}>0,05)$ persentase eliminasi bakteri Bacillus sp. pada mencuci tangan menggunakan metode 6 langkah dan 4 langkah. Selain itu, pada eliminasi total bakteri menunjukkan terdapatnya perbedaan signifikan $(\mathrm{p}<0,05)$ persentase eliminasi bakteri secara keseluruhan pada mencuci tangan menggunakan metode 6 langkah dan 4 langkah.

\section{Pembahasan}

Penelitian ini menemukan adanya variasi jumlah bakteri pada tangan yang pada sampel sama seperti hasil penelitian yang dilakukan oleh Edmonds-Wilson dkk.20 Hal ini disebabkan oleh terdapat bakteri residen yang secara konstan berada pada tangan ditambah dengan paparan lingkungan akan menambah jumlah bakteri pada tangan. ${ }^{21}$

Setelah mencuci tangan, terjadi penurunan jumlah koloni bakteri pada kedua kelompok. Penurunan jumlah koloni bakteri Bacillus sp mencapai $0 \mathrm{cfu} / \mathrm{ml}$ pada kedua metode mencuci tangan. Hal ini dapat dijelaskan melalaui hasil penelitian yang dilakukan oleh Kapil dkk yang menunjukkan bahwa bakteri transien lebih sensitif terhadap desinfektan dari pada bakteri residen pada tangan. ${ }^{22}$ Bacillus $s p$ merupakan mikroorganisme transien sehingga dapat dieliminasi hingga 0 dengan mencuci tangan menggunakan desinfektan. Namun, penurunan jumlah bakteri Bacillus sp. yang signifikan tidak tampak pada penelitian ini. Hal ini disebabkan karena jumlah koloni Bacillus sp yang ditemukan pada tangan sebelum cuci tangan tidak terlalu banyak sehingga tidak tampak penurunan yang 
bermakna setelah cuci tangan. Hal ini disebabkan oleh keberadan Bacillus sp yang merupakan bakteri transien pada tangan akan berinteraksi dengan lingkungan pada tangan seperti $\mathrm{pH}$ pada kulit tangan yang rendah, asam lemak pada sekresi sebasea yang banyak, dan keberadaan lisozim pada tangan yang akan mengurangi jumlah Bacillus tersebut. ${ }^{23}$

Penurunan jumlah total bakteri pada tangan secara signifikan $(\mathrm{p}<0,05)$ ditemukan pada kelompok yang mencuci tangan menggunakan metode 6 langkah pada seluruh area swab di tangan sedangkan mencuci tangan metode 4 langkah secara umum tidak memperlihatkan penerunan secara signifikan ( $p>0,05)$.

Dari penelitian ini diperoleh hasil bahwa ratarata persentase eliminasi bakteri Bacillus sp. adalah lebih dari $80 \%$ pada kelompok yang mencuci tangan menggunakan metode 6 langkah dan 4 langkah. Hal ini didukung oleh penelitian yang dilakukan oleh Lipinwati dkk yang hasilnya adalah persentase eliminasi bakteri pada tangan dapat mencapai $75 \%$ bahkan lebih. ${ }^{24}$ Namun, hasil rata-rata persentase eliminasi keseluruhan bakteri pada tangan yang ditemukan menunjukkan perbedaan yang signifikan antara kelompok yang mencuci tangan menggunakan metode 6 langkah dan 4 langkah. Pada kelompok yang mencuci tangan menggunakan metode 6 langkah, persentase eliminasi terendah adalah $75 \%$ sedangkan pada kelompok yang mencuci tangan menggunakan metode 4 langkah, persentase eliminasi terendahnya adalah 31\%. Hasil ini membuktikan bahwa mencuci tangan 6 langkah masih menduduki peringkat pertama dalam hal keefektifan mencuci tangan. Penelitian Reilly dkk juga memperkuat kesimpulan tersebut yang mana pada tahun 2016, Reilly dkk membandingkan metode 6 langkah WHO dan metode 3 langkah CDC. Hasil yang mereka peroleh dari penelitian tersebut adalah metode 6 langkah WHO memiliki persentase eliminasi bakteri yang signifikan dibandingkan metode 3 langkah CDC. 16

\section{Simpulan}

Berdasarkan penelitian yang dilakukan diperoleh bahwa tidak terdapatnya perbedaan persentase eliminasi bakteri Bacillus sp. pada mencuci tangan 6 langkah dan 4 langkah. Namun, terdapat perbedaan persentase eliminasi bakteri secara keseluruhan pada mencuci tangan 6 langkah dan 4 langkah. Untuk itu, dalam penerapan dalam klinis maupun sehari-hari diharapkan untuk mencuci tangan dengan 6 langkah sesuai tahapan WHO.

\section{Ucapan Terima Kasih}

Terima kasih kepada semua pihak yang telah membantu dalam pelaksanaan penelitian ini.

\section{Daftar Pustaka}

1. Ananthakrishnan AN, McGinley EL. Infection-related hospitalizations are associated with increased mortality in patients with inflammatory bowel diseases. J Crohns Colitis. 2013;7(2):10712.

2. Ogwang M, Paramatti D, Molteni T, Ochola E, Okello TR, Ortiz Salgado JC et al. Prevalence of hospitalassociated infections can be decreased effectively in developing countries. J Hosp Infect. 2013;84(2):13842.

3. WHO. The burden of healthcare-associated infection worldwide. 2016. http://www.who.int/gpsc/country_work/burden_hc ai/en/ - Diakses pada 1 Oktober 2018.

4. Ventola CL. The antibiotic resistance crisis: part 1: causes and threats. P T. 2015;40(4):277-83.

5. Allegranzi B, Bagheri NS, Combescure C, Graafmans W, Attar H, Donaldson L, et al. Burden of endemic health-care-associated infection in developing countries: systematic review and meta-analysis. Lancet. 2011;377:228-41.

6. Zimlichman E, Henderson D, Tamir O, Franz C, Song $P$, Yamin CK, et al. Healthcare-associated infections a meta-analysis of costs and financial impact on the US health care system. JAMA Intern Med. 2013;173(22):2039-45.

7. Kementrian Kesehatan RI. Permenkes RI Nomor 27 tahun 2017: Pedoman Pencegahan dan Pengendalian Infeksi di Fasilitas Pelayanan Kesehatan. Jakarta: Kementrian Kesehatan Republik Indonesia; 2017. http://ditjenpp.kemenkumham.go.id/arsip/bn/2017 /bn857-2017.pdf - Diakses pada 1 Oktober 2018.

8. Boyce JM, Pittet D. Guideline for hand hygiene in health-care settings. Recommendations of the healthcare infection control practice advisory committee and the HICPAC/SHEA/APIC/IDSA hand hygiene task force. Society for healthcare epidemiology of America/ Association for professionals in infection control/ infectious disease society of America. MMWE Recomm Rep. 2002;51(16):1-45.

9. Departemen Kesehatan Republik Indonesia. Kebersihan Tangan Mempengaruhi Keselamatan Pasien. Jakarta: Departemen Kesehatan RI; 2009. http://www.depkes.go.id/development/site/jkn/ind ex.html - Diakses tanggal 27 September 2018.

10. Ataee RA, Tavana AM, Khatami SM, Baghmaleki FA, Miry LS. The study effects of the handwashing on hands bacterial flora in the operating room. JHPSH. 2014;1(2):33-7.

11. Desiyanto FA, Djannah SN. Efektifitas mencuci tangan menggunakan cairan pembersih tangan antiseptic (hand sanitizer) terhadap jumlah angka kuman. KESMAS. 2013;7(2):75-82. 
12. Burton M. The effect of handwashing with water or soap on bacterial. Int J Environ Res Public Health. 2011;8(1):97-104.

13. Gold NA, Avva U. Alcohol Sanitizer. Treasure Island (FL): StatPearls Publishing;2018:1-12.

14. Rachmawati FJ, Triyana SY. Perbandingan anka kuman pada cuci tangan dengan beberapa bahan sebagai standarisasi kerja di laboratorium mikrobiologi FK UII. LOGIKA. 2008;5(1):3-13.

15. Komite PPIRS RSUP. DR. M. Djamil Padang. Panduan Kebersihan Tangan di RSUP DR. M. Djamil Padang. Ed.1. RSUP DR. M. Djamil Padang. 2014:10-3.

16. Reilly JS, Price L, Lang S, Robertson C, Cheater F, Skinner K, et al. A pragmatic randomized controlled trial of 6-step vs 3-step hand hygiene technique in acute hospital care in the United Kingdom. Infect Control Hosp Epidemiol. 2016;51:1-6.

17. Diarti MW, Rohmi, Achmad YSK, Jiwintarum Y. Karakteristik morfologi, koloni dan biokimia bakteri yang diisolasi dari sedimen laguna perindukan nyamuk. JKP. 2017;11(2):124-36.

18. Olearnik BS, Sochocka M, Zwolinska K, Ciekot J, Czarny A, Szydzik J et al. Comparison of microbiological and physicochemical methods for enumeration of microorganisms. Postepy Hig Med Dosw. 2014;68:1392-6.

19. Alhabsyi N, Mantiri FR, Kandou FEF. Perhitungan angka kuman dan indentifikasi bakteri dari alat makan pada restoran, warung makan permanen sederhana, dan pedagang makanan kaki lima di Kota Manado. PHARMACON. 2016;5(2);322-30.

20. Edmonds-Wilson SL, Nurinova NI, Zapka CA, Fierer $\mathrm{N}$, Wilson M. Review of human hand microbiome research. Elsevier. 2015;80(1):3-12.

21. Carroll KC, Hobden JA, Miller S, Morse SA, Mietzner TA, Barbara Detrick et al. Jawetz, Melnick, \& Adelberg's Medical Microbiology Twenty-Seventh Edition. New York: LANGE The Mc Graw Hill Companies;2016:169-71.

22. Kapil R, Bhavsar HK, Madan M. Hand hygiene in reducing transient flora on the hands of healthcare workers: an educational intervention. Indian J Med Microbiol. 2015;33(1):125-8.

23. Rosenthal M, Goldberg D, Aiello A, Larson E, Foxman B. Skin microbiota: microbial community structure and its potential association with health and disease. Infect Genet Evol. 2011;11(5):839-48.

24. Lipinwati, Rahman AO, Primayana. Perbandingan efektifitas cuci tangan tujuh langkah dengan air dan dengan sabun cuci tangan cair dalam menjaga kebersihan tangan pada mahasiswa/i FK UNJA. JMJ. 2018;6(2):137-45. 